\title{
SUBEPENDYMAL GIANT CELL ASTROCYTOMA WITH HIGH CHOLINE/CREATINE RATIO ON PROTON MR SPECTROSCOPY
}

\author{
Arnolfo de Carvalho Neto', Emerson L. Gasparetto², Isac Bruck ${ }^{3}$
}

\begin{abstract}
Objective: To report a case of subependymal giant cell astrocytoma (SEGA) in a patient with tuberous sclerosis, emphasizing the proton MR spectroscopy (MRS) findings. Case: A three year-old boy with tuberous sclerosis presented with a 3-month history of mild headache. The physical examination showed discrete mental retardation and multiple hypomelanic macules in the legs and back. MRI showed many cortical tubers and subependymal nodules. At the left foramen of Monro, there was a $15 \mathrm{~mm}$ nodule, with heterogeneous signal on T1 and T2-weighted images, and strong enhancement after contrast administration. MRS study (multi-voxel PRESS, TE $=144 \mathrm{~ms}$ ) showed the following ratios: a) left foramen of Monro nodule N-acetylaspartate (NAA)/creatine $(\mathrm{Cr})=0.93$ and Choline $(\mathrm{Cho}) / \mathrm{Cr}=1.6$ and b) at the right Monro foramen NAA/Cr=1.56 and $\mathrm{Cho} / \mathrm{Cr}=1.29$. Conclusion: The MRS performed at the SEGA may show high $\mathrm{Cho} / \mathrm{Cr}$ and low NAA/Cr ratios, similar to the other brain neoplasms. As a consequence, MRS may be a valuable tool for the early detection of neoplastic transformation of subependymal nodules near the foramina of Monro in patients with tuberous sclerosis.
\end{abstract}

KEY WORDS: subependymal giant cell astrocytoma, proton magnetic resonance spectroscopy, tuberous sclerosis.

\section{Astrocitoma subependimário de células gigantes com alta relação colina/creatina à espectros- copia de prótons por ressonância magnética}

RESUMO - Objetivo: Relatar caso de astrocitoma subependimário de células gigantes (ASCG) em paciente com esclerose tuberosa, enfatizando os achados de espectroscopia de prótons por ressonância magnética (EPRM). Caso: Um menino de três anos de idade apresentou-se com cefaléia por três meses. 0 exame físico demonstrou retardo mental discreto e múltiplas máculas hipomelanóticas no dorso e pernas. A ressonância magnética (RM) evidenciou múltiplos túberes corticais e nódulos subependimários. No forame de Monro esquerdo foi observado um nódulo de $15 \mathrm{~mm}$, com sinal heterogêneo nas imagens ponderadas em T1 e T2, e realce intenso após a administração de contraste. A EPRM (multi-voxel PRESS, TE=144ms) demonstrou as seguintes relações: a) no nódulo no forame de Monro esquerdo $\mathrm{N}$-acetilaspartato (NAA)/creatina $(\mathrm{Cr})=0,93$ e colina (Cho)/Cr=1,6 e b) no forame de Monro direito NAA/Cr=1,56 and $\mathrm{Cho} / \mathrm{Cr}=1,29$. Conclusão: A EPRM pode demonstrar relações altas de Cho/Cr e baixas de NAA/Cr em pacientes com ASCG, semelhante a outros tumores cerebrais. Sendo assim, a EPRM pode representar importante ferramenta diagnóstica na deteç̧ão precoce de transformação neoplásica de nódulos subependimários próximos ao forame de Monro em pacientes portadores de esclerose tuberosa.

PALAVRAS-CHAVE: astrocitoma subependimário de células gigantes, espectroscopia de prótons por ressonância magnética, esclerose tuberosa.

Subependymal giant cell astrocytoma (SEGA) is a tumor that typically occurs in the lateral ventricles near the foramina of Monro. The incidence of SEGA in tuberous sclerosis complex (TSC) varies from $5 \%$ to $14 \%^{1-3}$. Although this tumor is considered specific for TSC, there are reports of patients with SEGA who have none of the other stigmata of TSC. Usually these tumors grow slowly, but enlarge enough to cause increased intracranial pressure, seizures, and focal neurological signs ${ }^{3,4}$. The computed tomography (CT) and magnetic resonance imaging (MRI) are useful in non-invasive investigation of these tumors. Moreover, there are several reports of the CT and MRI aspects of the SEGA. Typically, the tumors are

Departments of Diagnostic Radiology ${ }^{1,2}$ and Neuropediatrics ${ }^{3}$, University of Parana School of Medicine and DAPI - Diagnóstico Avançado por Imagem'1, Curitiba PR, Brazil.

Received 22 February 2006, received in final form 11 May 2006. Accepted 19 June 2006.

Dr. Arnolfo de Carvalho Neto - DAPI, Diagnóstico Avançado por Imagem - Rua Brigadeiro Franco 122 - 80430-210 Curitiba PR - Brasil. E-mail: arnolfocarvalho@hotmail.com 
described as heterogeneous lesions occurring near the Monro foramina, presenting with variable enhancement after intravenous contrast injection ${ }^{4-8}$.

However, there are no reports of imaging features of SEGA regarding new advanced MRI techniques, such as proton magnetic resonance spectroscopy (MRS). MRS allows non-invasive biochemical evaluation of the brain, and it has been used in the investigation of several pathologies, such as brain tumors, degenerative diseases, metabolism born errors and developmental retardation ${ }^{9,10}$. In MRS, the most intense signal in the proton MR spectrum of brain originates from the $\mathrm{N}$-acetyl groups, mainly $\mathrm{N}$-acetylaspartate (NAA). Less intense signals arise from creatine plus phosphocreatine $(\mathrm{Cr})$ and choline-containing compounds (Cho). $\mathrm{N}$-acetylaspartate is localized exclusively in neurons and neuronal processes in the mature brain, and it can be used as a neuronal marker. Decreased NAA has been observed in areas of neuronal loss or dysfunction. creatine compounds, which may be more concentrated in glia than neurons, is relatively homogeneously distributed in normal brain and can be used as an internal standard in this circumstance. Choline is a component of phosphoglyceride and it is, therefore, a major constituent of cell membranes. As a result, the signal from Cho detected on MRS increases in conditions associated with high cell membrane turnover, such as tumors ${ }^{9,10}$. Although extensively applied as a differential diagno- sis tool in neuroimaging, to our knowledge there are no previous studies investigating the MRS findings in patients with SEGA.

We present the MR findings of a patient with TSC and a SEGA near to the Monro foramina, emphasizing the MRS pattern of this tumor.

\section{CASE}

A three year-old boy with TSC presented with a 3-month history of mild headache. The physical examination showed discrete mental retardation and multiple hypomelanic macules in the legs and back. History of cardiac rhabdomyomas and West syndrome were also referred. The infantile spasms and EEG pattern of hipsarhythmia, present since he was eight months-old, were been controlled with vigabatrin. The parents signed the informed consent and agreed with the study.

The patient underwent a MRI at the 1.5T GE LX echospeed plus (General Eletric Medical Systems, Milwaukee, Wis). Morphologic evaluation was performed and the following sequences were obtained (DFOV $=24 \mathrm{~cm}$ and slice thickness $=5.0 \mathrm{~mm}$ axial): "FLAIR" (TR=1100 ms, Tl=2200 ms and $T E=105 \mathrm{~ms}$ ), coronal FSE T2-weighted ( $T R=8000 \mathrm{~ms}$ $T E=102)$, axial GRE T2*-weighted ( $T R=667 \mathrm{~ms}, T E=25 \mathrm{~ms}$ and $F A=20^{\circ}$ ), axial FSE T1-weighted (TR=500 ms TE=7.9 ms) before and after gadolinium IV injection (Fig 1) and GRE 3D T1-weighted (TR=10 ms TE=4.2 ms slice thickness=1.6 $\mathrm{mm}$ ). The MRS was performed with multi-voxel PRESS technique with $\mathrm{TR}=1500 \mathrm{~ms}$ and $\mathrm{TE}=144 \mathrm{~ms}$ and rectangular FOV in axial plan at the Monro foramina level (Fig 2). The MR spectra were obtained at each side of the foramina of

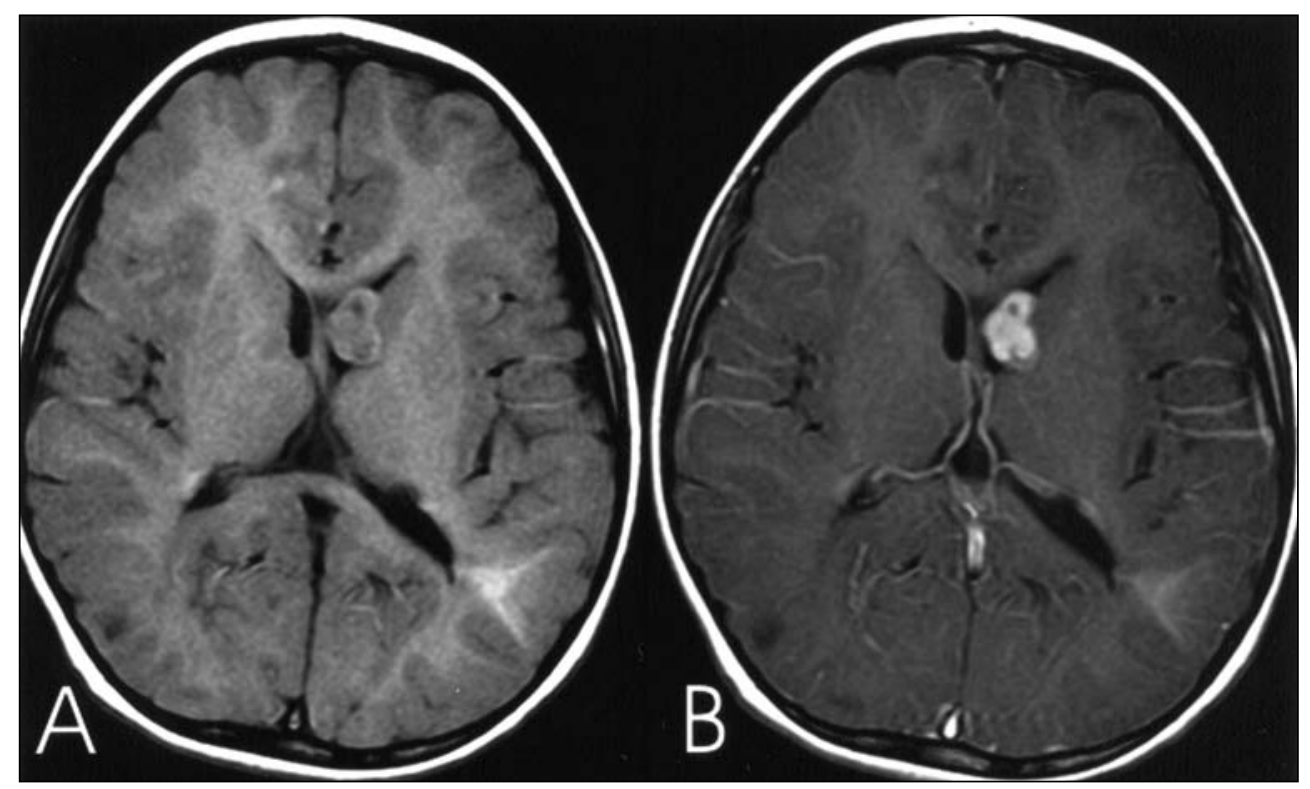

Fig 1. (A) Axial T1 weighted MRI before contrast administration shows a large left foraminal nodule promoting mild left lateral ventricle enlargement. Bilateral cortical tubers are also seen. (B) Axial T1 weighted MRI post-contrast administration demonstrates strong enhancement of the left Monro foramen nodule. 


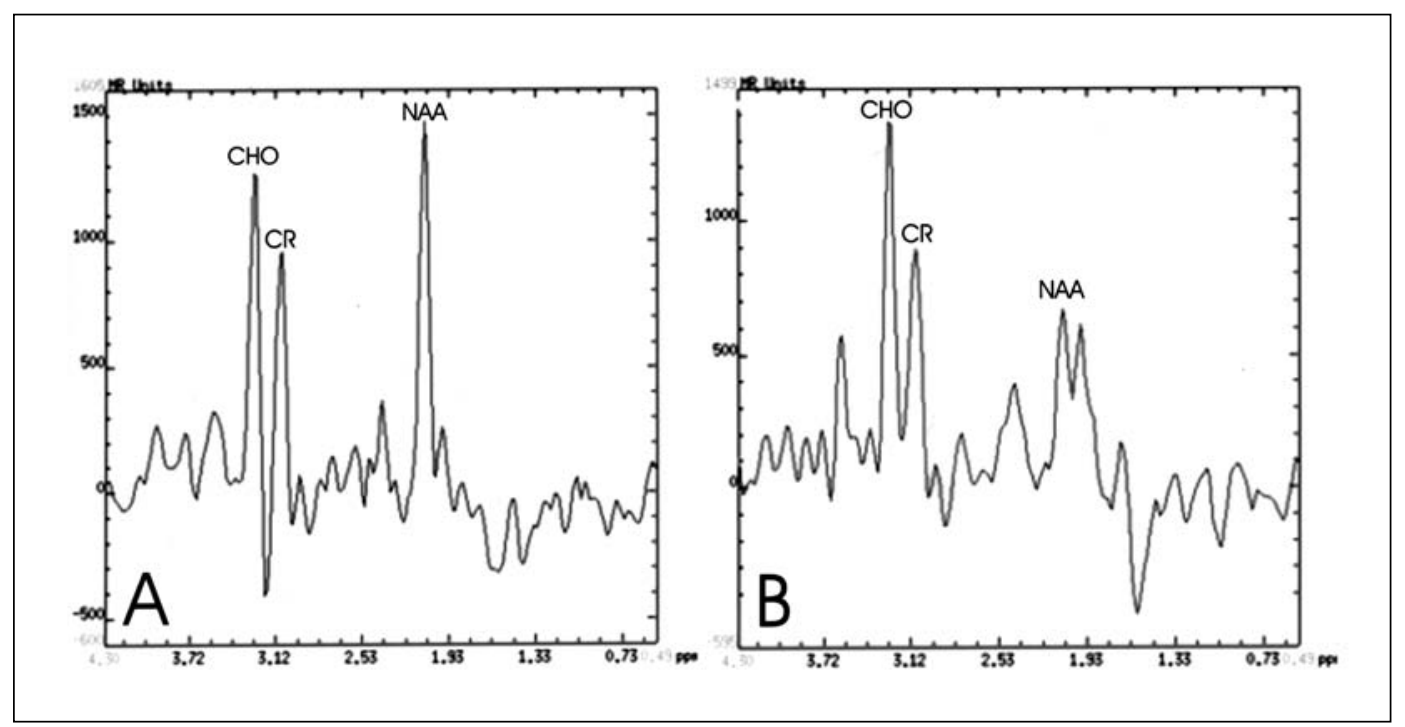

Fig 2. MRS multi-voxel (PRESS TE=144) at right (A) and left (B) foramina of Monro, showing elevated Cho/Cr and decreased $N A A / C r$ on the left.

Monro and the exams were analyzed by a commercial program (Functool 2000).

MRI showed many cortical tubers and subependymal nodules in both cerebral hemispheres. At the left foramen of Monro, there was a $15 \mathrm{~mm}$ nodule, with heterogeneous signal on T1 and T2-weighted images, and strong enhancement after contrast administration. Mild enlargement of the left lateral ventricle was also seen. The MRS studied showed the following ratios: a) left foramen of Monro nodule NAA/Cr=0.93 and $\mathrm{Cho} / \mathrm{Cr}=1.6, \mathrm{~b})$ at the right foramen $\mathrm{NAA} / \mathrm{Cr}=1.56$ and $\mathrm{Cho} / \mathrm{Cr}=1.29$, and $\mathrm{c}$ ) at the right basal ganglia NAA/Cr=1.70 and $\mathrm{Cho} / \mathrm{Cr}=1.24 \mathrm{~d}$ ) at the left basal ganglia $\mathrm{NAA} / \mathrm{Cr}=1.72$ and $\mathrm{Cho} / \mathrm{Cr}=1.24$.

\section{DISCUSSION}

The SEGA is the most frequent brain tumor in patients with TSC. The histogenesis of this tumor is not well understood. Previous studies have been reported glial (astrocytic or rarely ependymal), neuronal or mixed glial-neuronal differentiation. Although SEGA usually grow slowly, they may be responsible by substantial morbidity and mortality in patients presenting with TSC. Death occurs due to increased intracranial pressure caused by the obstruction of cerebrospinal fluid flow at the foramina of Monro, or less frequently secondary to intratumoral hemorrhage. In the present case, the tumor was causing mild enlargement of the left lateral ventricle ${ }^{1,2,4}$.

The diagnostic definition of SEGA is not only based on histological findings because they are similar to the other subependymal nodules and cortical tubers. Some authors suggested that this diagnosis could be established by the size of the nodules (larg- er than 10-12 mm), pattern of contrast enhancement, presence of calcifications and rate of growing 1,2,4,5. A useful set of criteria, adopted by Baron and Barko$v^{\text {vich}}{ }^{7}$, defined that a lesion larger than $12 \mathrm{~mm}$ in diameter promoting hydrocephalus is suggestive of SEGA. In addition to these findings, contrast enhancement of the lesion was highly indicative of SEGA. In our case the nodule was near to the left foramen of Monro, had $15 \mathrm{~mm}$ in diameter, showed strong and heterogeneous enhancement, and it was associated with mild enlargement of the left lateral ventricle.

It is not clear in the literature when a hamartomatous nodule turns into a neoplasm (SEGA), or even if it does occur. Waiting for growing or hydrocephalus add risks to TSC patients and costs for the followup $^{2,4,6,8}$. It is important to make early diagnosis of these tumors, and, if possible, characterizing the subependymal nodules with potential to neoplastic degeneration, with close follow-up. In this regard, through an increase in the $\mathrm{Cho} / \mathrm{Cr}$ ratio, the MRS has the potential to detect changes in cellular multiplication even before the nodule grown. In this reported case, the proton MRS at the SEGA showed high $\mathrm{Cho} / \mathrm{Cr}$ (1.60) and decreased NAA/Cr (0.93) ratios when compared to the contralateral Monro foramen $(\mathrm{Cho} / \mathrm{Cr}=$ 1.29, NAA/Cr=1.56) or basal ganglia $(\mathrm{Cho} / \mathrm{Cr}=1.24$, $\mathrm{NAA} / \mathrm{Cr}=1.70$ ). This MRS profile is suggestive of neoplastic transformation.

In conclusion, MRS performed in patients presenting with SEGA may show high $\mathrm{Cho} / \mathrm{Cr}$ and low NAA/Cr ratios, similar to other brain neoplasms. As a consequence, MRS may be a valuable tool for the early de- 
tection of neoplastic transformation of subependymal nodules near the foramina of Monro In patients with TSC. Further prospective studies investigating the MRS features of patients presenting with TSC should be conducted, trying to establish its potential for the early diagnosis of SEGA.

\section{REFERENCES}

1. Curatolo P, Verdecchia M, Bobardieri R. Tuberous sclerosis complex: a review of neurological aspects. Eur J Paed Neurol 2002;6:15-23.

2. Caldemeyer KS, Mirowski GW. Tuberous sclerosis: Part I. Clinical and central nervous system findings. J Am Acad Dermatol 2001;45:448-449.

3. Jozwiak S, Schwartz RA, Janniger CK, Bielicka-Cymerman J. Usefulness of diagnostic criteria of tuberous sclerosis complex in pediatric patients. J Child Neurol 2000;15:652-659.

4. Nishio S, Morioka T, Suzuki S, Kira R, Mihara F, Fukui M. Subepen- dymal giant cell astrocytoma: clinical and neuroimaging features of four cases. J Clin Neurosci 2001;8:31-34.

5. Christophe C, Sekhara T, Rypens F, Ziereisen F, Christiaens F, Dan B. MRI spectrum of cortical malformations in tuberous sclerosis complex. Brain Dev 2000;22:487-493.

6. Nabbout R, Santos M, Rolland Y, Delalande O, Dulac O, Chiron C. Early diagnosis of subependymal gigant cell astrocytoma in children with tuberous sclerosis. J Neurol Neurosurg Psychiatry 1999;66:370-375.

7. Baron Y, Barkovich J. MR imaging of tuberous sclerosis in neonates and young infants. Am J Neuroradiol 1999; 20:907-916.

8. Beems T, Grotenhuis JA. Subependymal giant-cell astrocytoma in tuberous sclerosis: endoscopic images and the implications for therapy. Minim Invasive Neurosurg 2001;44:58-60.

9. Mizuno S, Takahashi Y, Kato Z, Goto H, Kondo N, Hoshi H. Magnetic resonance spectroscopy of tubers in patients with tuberous sclerosis. Acta Neurol Scand 2000;102:175-178.

10. Mukonoweshuro W, Wilkinson ID, Griffiths PD. Proton MR spectroscopy of cortical tubers in adults with tuberous sclerosis complex. Am J Neuroradiol 2001;22:1920-1925. 